\title{
Christian Missionaries and Their Impact on Socio - Cultural Development - Undivided Koraput District a Study
}

\author{
Dr. Raghumani Naik \\ Head, Department of History, NSCB Jr College, Sambalpur
}

\begin{abstract}
Before the coming of Christian Missionaries the undivided Koraput District of South Odisha was passing through a 'Dark Age'. Hilly and undeveloped, it was inaccessible and so isolated from the mainstream for century together. The region could not see the light of the modern world and remained backward. The inhabitants were up to their neck in evil practices like superstition, female infanticide, child marriage, Mariah sacrifice, seclusion of women, bethi and goti system, rigidity of caste system and untouchability. The lower caste people were indigent, ignorant, illiterate, and superstitious and considered untouchable, outcaste and uncivilized. Above all, it was a malaria prone district and there was no health care facility. So, the people took resort to supernatural power. They were worshipping various elements of nature, ancestors and many Gods and Goddesses. In these critical circumstances, the Christian Missionaries came on $15^{\text {th }}$ May, 1882 A.D. and heralded a new epoch in socio- cultural development of this district. They introduced and implemented handful of welfare schemes such as eradication of illiteracy, economic upliftment, and social mobilization, consciousness of health and hygiene and gender identity of women. Thereafter, a tremendous impact of missionaries' activities was observed on the people of this area.
\end{abstract}

Keywords: Economic, Educational, Health, Religious Tribals.

\section{Introduction}

The $19^{\text {th }}$ Century witnessed a great intellectual upheaval all over Orissa. The rational mind interrogated the inner purport of social customs and religious forms. In course of time, a series of socio-religious movements with reformative sinew began to renovate the society and rationalized religion. These movements raised its voice against superstitions, blind beliefs and irrational practices. In this connection, the missionaries played a vital role. They were inspired with civilizing mission to eradicate the socio-cultural evils prevailed in the undivided Koraput district.

It was the home land of the aboriginals. These people were considered outcaste and untouchable. Most of them were poor and leading miserable and deplorable life. Hence, the social status and suffering of the lower caste people were indescribable. The undivided Koraput district was full of mountainous regions and hilly tracts. Due to inaccessibility, it was isolated from outside world for century together and remained backward and undeveloped. That's why, people of this area could not see the light of modern world and were rolling on a number of superstitious beliefs.

There were various problems besetting this district such as child marriage, infanticide, seclusion of women, bethi and goti system, mariah sacrifice, superstition and illiteracy. There was no female education and gender identify in this area. Rigidity of caste system and untouchability made social life hellish. The high caste people used to oppress and suppress the lower caste people. The sahukars, moneylenders, zamindars, royal officers and police personnel had vampire in them. Being a malaria prone district health hazard was a regular feature [1] and people solely depended upon sorcery, magic spells of local physicians like Dissaris, Bejjus, Siras, Guniyas and Gurumains [2] and were dying without proper medical treatment. Above all, the British hegemony aggravated the untold suffering and misery of the people. Therefore, prior to the advent of the missionaries, this district was passing through "Dark Age"

In this critical circumstance, the missionaries came to Koraput district on $\mathbf{1 5}^{\text {th }}$ May, 1882 A.D [3] with two noble objectives i.e. "Arise and Shine" and raised a ray of hope for the despondent, hopeless, helpless, downtrodden and desolate people and heralded a new epoch in the history of Koraput district. Their noble objectives were directed to changing the society. The missionaries had to struggled for existence in the initial stage and suffered a lot due to the bureaucratic hassles, stunt opposition and threatening both from the police personnel and the high caste people [4] but they never lost their spirits rather remained determined to continue the evangelical activities in this district in the face of all that came their way. They ultimately succeeded in carrying out their work in this hilly district because of their dedication, sacrifice, determination and benevolent motive.

Thereafter, the history of Koraput witnessed a tremendous transformation in the socio, economic, educational, health and religious spheres. There was in fact historic leap from tradition to modernity, darkness to light, superstition to reason, illiteracy to literacy, ignorance to knowledge, enmity to fraternity, unhealthiness to 
salubrity, Violence to non-violence, immolation to prayer, isolation to assemblage and casteism to social mobility.

The missionaries introduced and implemented some welfare programmes for the development of the people and kept up their work with "missionary spirit" and "work of mercy". In fact, the missionaries brought revolutionary changes in all spheres which had never happened earlier in this region. They did a tremendous job for the neglected people and it was really praiseworthy. Some of unbelievable achievements and their impact on the society and people are briefly discussed below:

\section{Social Impact - A Commendable Step For Social Renovation And Regeneration}

The existing society of this district was traditional and conservative where rigidity of caste system and untouchability was widely practised. The supremacy of high caste people was the impediment for the social mobilization and development of the common people. The lower caste people were denigrated and exploited by the high caste people [5]

So, out of frustration and discontentment caused due to social humiliation and caste prejudices, the lower caste people slowly tilted towards Christianity. In this new religion, there was no caste system, and any hard and fast rules. The missionaries adopted some measures to minimize caste system in the caste ridden society.

First of all, the missionaries attracted both tribal and non-tribal people towards Christianity by interpreting one religious concept, one God, one caste and propagated the Gospel of God that all are the children of the Almighty. There is only caste i.e. mankind and only one religion that is humanity. So, there is no disparity among us. We are all the children of His Almighty. We are brothers and sisters as our creator is one. Man is known by his work not by his caste. Caste system has been created due to division of labour in the society. This religion propounded fatherhood of God and brotherhood of man and laid stress on monotheism.

Secondly, the missionaries established a number of Churches and organized Sunday gatherings, festivals like XMas, Good Friday, Easter where common people met and exchanged their words, sat together and ate together and later on invited one another to their homes on special occasions. So, fellow feeling was developed that led to social interaction and social mobilization. This is how, the dynamics of social change found expression through religious institutions took place.

The missionaries set up mission schools for the children of converted Christians but it was soon found that even non - Christian students flocked to these educational institutions. The admissions of students, irrespective of caste and religion, facilitated for the promotion of inter-caste and inter-communal amity. They met each other daily, sat together, exchanged their views cordially, made friendship and helped one another for their studies. Non-Christians teachers were also appointed in the mission schools to teach the students. Thereafter, a sort of cultural oscillation went on in the minds of the first generation of converted Christians.

Marriages were held without any caste barrier. The new class of Christians followed the principles of discipline, mutual help and cleanliness of body and mind. The missionaries laid emphasis on the development of character in the converted Christians. Virtues of Christianity like honesty, benevolence, decency, and respect for truth and love, were infused into their minds. They were expected to be the models of morality and humanitarianism.

The missionaries built separate colony known as mission compound and took care of the converted Christians and provided all facilities so that they could live in the society, free from social taboos. However, this people felt secluded and did not keep relationship with outside people. On the other hand, the missionary activities broke the stagnation of the traditional Hindu society. Their campaign posed a big challenge to the complacency of the prevailing social system. Social banes like untouchability, caste system, and seclusion of women, human sacrifice, female infanticide, child marriage and forced celibacy of widows, Bethi and Goti system which were widely prevalent in the society started ebbing out because the missionaries drew attention of the Govt. towards the presence of various social evils and prayed to abolish from the society through legal means. The social mobilization was one of the great contributions of the missionaries for the people of this area. It had a huge impact both on the people and the society.

\section{Economic Impact- Noble Steps To Uplift The Converted Christians}

Koraput was a hilly tract and mountainous regions and agricultural lands were very scanty. Besides forest products, the tribals were occasionally doing shifting cultivation, terrace cultivation and seasonal agriculture but it was not enough for them. So, the Tribal economy was totally based on nature. Bethi and Goti system was prevalent in the society and the Sahukars, Moneylenders and Zamindars used to charge high rate of interest when they were giving loans to the people. The economic condition of the Dalits was also very worse. They were mainly doing manual jobs, small trades, daily wage, trumpeting and music playing and eking out their livelihood. They had to live half starved and so their standard of living was very miserable. It was therefore sinaquanon for the mission to adopt some economic measures for their development.

As a first step, the missionaries engaged the uneducated converted Christians in various manual works such as gardening, marketing, cooking, and tending horses and on plantation work, agricultural field and coffee garden. 
The missionaries had established a Tea Department Labour Association (TDLA) with its headquarters in Koraput and young boys from Jeypore were sent to Assam for keeping the tea cultivation going. Besides, the missionaries set up an industrial school (1901), a vocational training centre (1902), a vocational school (1906) [6] and a weaving school all at Koraput, and an agricultural farm at Nandapur etc and imparted training to the people to be fit for their business and to do separate business for them. That meant, the missionaries wanted to create skilled labourers in the society and engage them in various economic programmes launched by them. Financial assistance was also provided so that they could to these trained people to make their own ways.

The Jeypore Evangelical Lutheran Church established a weaving Training School and subsequently a Co-operative society called 'Koraput Weavers Co-operative Society' to impart training to the poor weavers. Besides weaving, they were also giving training on making baskets, weaving mats, carpentry, blacksmith work, bamboo work, weaving and pottery etc [7] To provide financial assistance to the trained people, banks, such as Koraput Savings and Lending Bank (1903), Small Savings Bank (1906), Nabarangapur Co-operative Central Bank and Credit Bank (Report of JELC) were set up. By doing so, the missionaries could save the poor from the clutches of the indigenous money lenders and Zamindars who were charging high rates of interest and the people remained under heavy debts and leading the life of dire distress and dismal. The effective annual interest rate they kept was $5 \%$, whereas the interest rate usually charged by the money lenders was as high as $350-400 \%$ during that time [8]

Agricultural loans were also provided to the farmers for the development of agriculture. Money was also lent to non-Christians. The pioneering missionaries who had undertaken this task were Rev. Timmcke and Rev. Huber.

Exploitation, the worst hazard of tribal economy, was drastically decreased because of the introduction in various economic activities. Many educated Christians are now holding government jobs, even judicial and civil services and are lawyers and teachers. They are no more exploited and suppressed by high caste people and Sahukars. The practices of Goti and Bethi system which were widely prevalent in the district met their end due to continuous persuasion by the missionaries to Government and they were abolished in 1948. The missionaries also built market complexes and bought acres of land as the permanent sources of maintenance of churches and salary for the employees for future.

\section{Impact Of Education - A Ray Of Hope And Opportunity For Employment}

The missionaries keenly observed that most of the people were grossly illiterate, ignorant and superstitious. They used some jargons for exchanging their views but it was too intelligible for the missionaries. It was realized that without providing education, Gospel of God would not reach to them. Therefore, the missionaries introduced education in this area which was blessing in disguise for the people in the long run.

The aim of missionary education was to ensure moral enlightenment and economic security for the people and increase the desire for the readers and the new converters. Any converted Christian after passing out standard 3rd and $7^{\text {th }}$ was immediately appointed as pastor. Any one, who knew writing and reading, was appointed as Gurus, Catechists, preachers and office bearers. So, missionary educations helped generate job. The missionaries established Primary, Elementary, Upper Primary, M. E Schools, High Schools, Theological seminary, Adult Education, Sunday Schools, Night schools and introduced zenana system for high caste women and an Elementary Teacher Training School was established at Jeypore [9] for development of education. Now, there are 44 U.P schools, 05 M.E.Schools.05 High Schools, 01 Theological Seminary and 01 Teacher's Training school at Jeypore all under the good supervision of JELC.

The missionaries' efforts in spreading education among the common people aroused consciousness in the indigenous mind. However, all the benign efforts of the missionaries to spread education were a cloak on the idea of spreading Christianity but the missionaries really rendered a valuable service and did a considerable amount of spade work for the growth and development of education in this inaccessible area.

\section{Religious Impact - Movement From Pantheism To Monotheism}

The power of religious belief is always a strong factor qualifying human behaviour. As an integral part of the society, religion exercises great influence on the people in their social habits. The Adivasis were purely religious and they were the 'Lovers of Nature' and worshipping various elements of Nature. Besides that, they were worshipping idols and offering animals, cocks and hens etc to their Gods and Goddesses to get their blessings. They were polytheist and pantheon. They widely believed in supernatural powers (magic, spells, spirits, and sorcery), Animism, animatisms, fetishism and anthropomorphism. Ancestral worship was also a part of their religion.

On the other hand, the missionaries went dead against idol - worship. Polytheism, magic spells sorcery, spirits, animal sacrifice, rites, rituals, customs, traditions, ceremonies etc and propounded monotheism. Christianity believes in simple prayers and love of humanity. They propagated that Jesus is the creator, liberator, and saviour of mankind. He symbolizes living God and is the protector of mankind. The Christian Missionaries, behaved rudely towards the converted Christians who by chance attended any Hindu ceremonies 
or social gatherings. They prohibited and prosecuted them severely. They were antagonist to Hinduism. The missionaries introduced purely Christian based curriculum and taught against Hinduism.

However, Christianity propounded more humanistic values like love, affection, charity, chastity, fraternity and sacrifice. It is a religion of peace and it rejected all hard and fast rules and elaborates rites and rituals found in Hinduism. In this religion, there is no room for caste system and untouchability. Fatherhood of God and brotherhood of mankind is its motto. It needs only Sunday worship simple prayer, devotion and selfpurification and there is no need of offering animals. Unlike Hinduism, this religion is less expensive and so is the religion of mass. There is no restriction to anybody irrespective of caste, creed, colour and sex to follow the simple principles of Christianity. There is no fear of clutches of priests and high endowment and gift in religious activities. By observing such traits and motivation of the missionaries, the people spontaneously accepted Jesus Christ as their saviour or Messiah. The lower caste people accepted Christianity due to socio -economiceducational cause. So, it is seen that, there was a drastic change among the people. They moved from violence to peace and abandoned their aged long traditions and customs. In those days, being a Christian meant progress, protection, upliftment and peace. So, people impulsively dragged themselves towards Christianity and after that, this religion spread rapidly in this district.

There was a lasting impact on the existing system of worship. By this new religion, the Missionaries could change the people from violence to peace, cruelty to compassion, animal sacrifice to prayer and devotion, spirits and magic spells to believing in God only, polytheism to monotheism and superstition to reason. Through this religion, they were able to convince people to recognize their God and realize Him for the transmigration of Soul. So, Christianity had tremendous impact on the minds of the people regarding this religion. The missionaries were the only people who could realise the pathetic conditions of the people and tried to eradicate it and ultimately succeeded also.

No doubt, there was evil machination behind its evangelical activities but the roles played by the missionaries in various fields were noteworthy. They tried to renovate and rationalize the traditional society where everything was out of order and full of restriction. Later on a number of religious movements started in $19^{\text {th }}$ century to reform the society but the Christian missionaries are the fore runner of them.

\section{Impact Of Health And Hygiene - Makeover From Insanitary To Salubrity}

Koraput District was notorious as malaria prone region. Besides malaria, people were suffering from various lethal diseases and dying without proper medical treatment. During that time, sickness was viewed as the effect of supernatural power and people were taking help of sorcery and magic spells because they were thought to be the most effective way of curing a sick. Thus people were easily victimized by the local physicians namely Gurumains, Dissaris, Siras, Bejjus and Guniyas etc. and did not consult the then available physicians [10]. They were economically exploited by them and even at last they were losing their valuable lives.

The missionaries followed three missions such as preaching, teaching and healing. Through healing mission, the missionaries acquired some basic medical knowledge and started treating the sick people at the mission stations. They provided health care facility to the people by establishing clinics, dispensaries, Leprosy haven (1901), Ebenezer hospital (1909) at Kotpad, mobile health care system (1912) in rural areas, and later on they established grand hospitals like, Nabarangpur Christian Hospital (1952), Bissam Cuttack Christian Hospital (1954) and Nabajeevan Based Hospital (1978) at Doliambo.

While treating the patients, the missionaries would not forget to remember Jesus that He was curing the diseases. Though it was wrong interpretation yet people were bound to believe it after their recovery. In every medical centre a pastor was appointed to pray for the recuperation of the patients. Whatever might be the intentions behind the introduction of healthcare system of the missionaries, it was blessing in disguise for this region. Now hundreds of patients from faraway places are visiting these hospitals daily for their proper treatment and not knocking the doors of the local physicians. The medical services initiated by the missionaries had a tremendous impact on the people and it is more relevant at the present moment. Now, Government is giving much importance on health and hygiene of the people and establishing health care centres at every corner of the state. But, the missionaries were the precursors who introduced this medical system hundred years back in this hilly district.

\section{Impact On Tribal Society}

Since long days tribals had been isolated from the mainstream and leading secluded life. They were considered outcaste and neglected not only by the local zamindars, kings but also by the British Government, They remained backward and nobody took any steps for their improvement. The missionaries were the first people to come closer to the tribal society with bringing handful of welfare schemes for their development. Even some of the missionaries lost their valuable lives. Among the missionaries one who lost his valuable life for the betterment and amelioration of the tribal was Rev. R.Tauscher. He was affectionately called "BABA" by the tribal. The phrase 'missionary spirits' even today, symbolizes devotion and self sacrifice of the alien 
missionaries in the remotest hills and forests. The welfare activities taken up by them were called the 'work of mercy'.

\section{Conclusion}

Due to the untiring, dedicated and selfless service of the missionaries, not only the spiritual life that was transformed to a great extent but also the socio-economic life of the people of Koraput district especially the marginalized, unreached, poor tribal and Dalit people underwent a sea change. They had released the people from the bondage of blind belief, superstition, illiteracy, poverty and untouchability, etc. By their unflinching and impartial love and compassion, they did away with the stigma of dreadful diseases like leprosy, cholera, small pox, etc. and treated the ill and fed the starved. The welfare measures like the residential schools, mid-day meals, relief measures, stipend system, education, health and economic escalation that the government is taking today are only the replication of the footprint left by the missionaries in this inaccessible hilly region.

The challenge of the missionary movement was followed by an emphatic indigenous response. The denunciation of the traditional social structure evoked a sense of self-analysis in the minds of the educated people of Orissa who later carried on the movement of revival and reformation. The general infiltration of the missionary propaganda to the social structure initiated a change. Thus, the ideas and efforts of the missionaries acted and counter-acted to raise a reformed society in Orissa.

The missionary activities are a milestone in the hilly and mountainous district like Koraput. The tribal and Dalit people will remain indebted for ever for the selfless services rendered by the Christian missionaries.

\section{Reference}

[1] B.C. Padhi, "Socio -Economic Conditions of the Tribal under the British Rule, 1803 - 1936)" Punthi Pustak, Calcutta, 1992, (137 -151)

[2] R.C.S. Bell, “Odisha District Gazetteer Koraput Orissa, Calcutta, Govt.Press, Cuttack, 1945, (62)

[3] Anthon. Asha, "Church History from Breklum to Koraput” JELC Press, 1982, (11)

[4] Otto Waack,. "Church and Mission in India, Volume - I" ISPCR, Kashmere Gate, Delhi, $1997(264$ - 263)

[5] E. Gloyer, "Presentation of the Gospel to Hinduism" Year Book, 1933 (37)

[6] R. Tauscher, "Schleswig Holstein Evangelical Lutheran Mission Society" (154)

[7] Report of Secretary, Jeypore Evangelical Lutheran Church, Jeypore

[8] VFM Smruiti Sansad. (Cultural Heritage of Odisha,Volume XI, Koraput District” 2006 (578-579)

[9] R Tauscher,. "Schleswig Holstein Evangelical Lutheran Mission Society" 1939 (72)

[10] Ibid: (153) 